\section{UNIVERSITY}

OF DEBRECEN

FACULTY OF

HEALTH

NYíREGYHÁZA

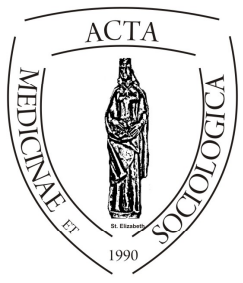

ACTA

MedSoc

VOLUME 5.

2014

\title{
Demográfiai, háztartási jellemzők
}

\author{
Malakucziné Póka Mária \\ Központi Statisztikai Hivatal, \\ Debreceni Főosztály
}

\begin{abstract}
The study presents the demographic and domestic characteristics of Nyíregyháza, one of the easternmost cities of Hungary. With the population of nearly 120 thousand, Nyíregyháza is the seventh most populated city of the country. The study is mostly based on census data and mainly focuses on the period after 2001, but also gives a short historcial overview. The census data provides a rich way to examine domesctic, family and educational features. Apart from presenting the tendencies - a descriptive and comparative analysis - the study considers county seats, national averages and the immediate environment - Szabolcs-Szatmár-Bereg county - as reference points. The data shows that the unfavourable demographic processes - eg. decline in birth rates, an ageing population, high unemployment, the shrinking number of marriages characterise the city, however, a greater role of traditions is also very much present.
\end{abstract}

Key words: natural increase and decrease, migration, age structure, educational attainment, ethnic, religious affiliation, employment level, household-, family structure

DOI: $10.19055 / \mathrm{ams} .2014 .5 / 12-13 / 2$

\section{A népesség száma}

A népszámlálási adatok alapján, azaz tízévenkénti periódusokkal mérve, Nyíregyháza lakónépessége 2011-ig tendenciájában emelkedett. A két legutóbbi, 2001. és 2011. évi cenzus közötti növekedés üteme azonban a korábbiaknál sze- 
rényebb, mindössze 1\%-hoz közeli volt. Ugyanezen időszakban az ország népessége 2,6\%-kal csökkent, és a Nyíregyházával azonos jogállású, vagyis a megyei jogú városok döntő többségének lélekszáma is kevesebb lett. A város közvetlen környezete, Szabolcs-Szatmár-Bereg megye népessége pedig az országos átlagot meghaladóan, 3,5\%-kal esett vissza.

A megyeszékhelyet a 2011. évi népszámlálás eszmei időpontjában (október 1-jén) 119,7 ezer fő lakta. A népszámlálási adatokból a népmozgalmi statisztikai információi alapján továbbvezetett nyíregyházi lakónépesség-szám 2013 elején 118,2 ezer fö volt, vagyis az adminisztratív forrásból származó adatok a 2011. évi népszámlálás után már a lakónépesség kisebb csökkenését mutatják.

Szabolcs-Szatmár-Bereg megye lakossága 21\%-ának lakóhelye Nyíregyháza. Ez, a többi megyeszékhely adott megyén belüli népesség-koncentrációjával összehasonlítva nem kiemelkedően magas, hiszen a megyeszékhelyek fele a nyíregyházinál nagyobb mértékü koncentrációval jellemezhető.

Nyíregyháza magyarországi viszonylatban nagyvárosnak számít, azaz a 100 ezer főnél nagyobb lélekszámú települések egyike a kilenc közül. Egyúttal az ország hetedik legtöbb lelket számláló települése a főváros, Debrecen, Szeged, Miskolc, Pécs és Győr után, megelőzve a nagyvárosok sorában Kecskemétet és Székesfehérvárt.

\section{A népesség számát alakító folyamatok}

Nyíregyháza lakosságának 2001. február 1-je és 2011. október 1-je közötti szerény növekedését kizárólag vándormozgalmi nyeresége magyarázza, hiszen a népességszámot alakító másik tényező, a születések és a halálozások eredője gyakorlatilag nulla volt ebben az időszakban.

\section{Vándormozgalom}

A vándorlások számbavétele számos bizonytalansági tényező mellett lehetséges. A népszámlálási vándorlási adatok számítással (kivonással) képződnek, figyelembe véve a lakónépesség számát és az adminisztratív forrásokból származó élveszületési, halálozási adatok eredményeként adódó természetes szaporodást, illetve fogyást. Az adminisztratív forrásokból származó vándorlási adatok pedig alapvetően a lakcímbejelentésen alapulnak, és megbízhatóságukat a polgárok bejelentési fegyelmezettsége nagyban befolyásolja.

A népszámlálási információk alapján, a belföldi és a nemzetközi vándorlásokat együttesen tekintve, Nyíregyháza folyamatosan migrációs többletet mutat, 
egy olyan megyében, amely az ország egyik legnagyobb népességleadó vidéke. Ez a többlet azonban a 2000-es években lényegesen szerényebb volt, mint az 1990-es években, amikor a rendszerváltáshoz kapcsolódó általános recesszió közepette nagymértékü volt a térségbe a visszaáramlás, így akkor jelentős -3 ezer főt meghaladó - vándorlási többlet alakult ki. A 2000-es években a vándorlási nyereség az előbbi harmadára csökkent, mivel fokozódott az elvándorlás. Az idevándorlások esetszáma is emelkedett, így a mérleg változatlanul pozitív marad ezekben az években is.

A vándorlások jellege (állandó vagy ideiglenes), iránya (belföldi vagy nemzetközi) szerinti vizsgálatokra az adminisztratív források alapján van mód. E szerint a belföldi, vagyis országhatáron belüli migrációs folyamatok Nyíregyházán is veszteséget mutatnak. A belföldi végleges jellegü (állandó) vándorlások egyenlege ugyanis veszteséges, amit a belföldi ideiglenes vándorlások nyeresége nem kompenzál. Hatásukra 2000-2010 között összességében néhány száz fős belföldi vándorlási hiány alakult ki. Ezt a veszteséget az évenként igen hektikusan alakuló, a 2000-es években évente átlagosan mintegy 100 fö körüli nyereséget okozó nemzetközi migráció kompenzálta, illetve ezen túl kisebb növekedést is lehetővé tett.

A belföldi állandó vándorlások hiánya a megye határain átnyúló vándorlásokból adódik, miközben a megye határain belüli állandó lakcímváltozások egyenlege pozitív a városra nézve. Az ideiglenes vándorlások összességében mért többletének forrása ugyancsak a megyén belüli vándormozgalom.

Kedvező, már a 2000-es évek legvégén elinduló változás, hogy az állandó belföldi vándorlások egyenlege pozitívvá válik (e vándorlások intenzitásának csökkenése mellett). Ugyanakkor az ideiglenes belföldi vándorlások felerösödnek, és a korábbiaktól eltérően veszteséget mutatnak. Összességében a belföldi migrációs veszteség mérséklődik.

\section{Természetes szaporodás, fogyás}

A városban az élveszületések és halálozások egyenlege az 1980-as években még jelentős természetes szaporodást eredményezett, miközben országosan már természetes fogyás mutatkozott. A természetes szaporodás megmaradt az 1990es években is, volumene azonban lényegesen szerényebbé vált a korábbinál. A 2000-es években megszünt a nyereség, a 2010-es évektől pedig Nyíregyházán is állandó jelleget ölt a természetes fogyás. (1. ábra.) Mindazonáltal az alapvetően a születések alacsony szintje által vezérelt permanens természetes fogyás a városban mintegy három évtizedes késéssel következett be az országoshoz képest. 


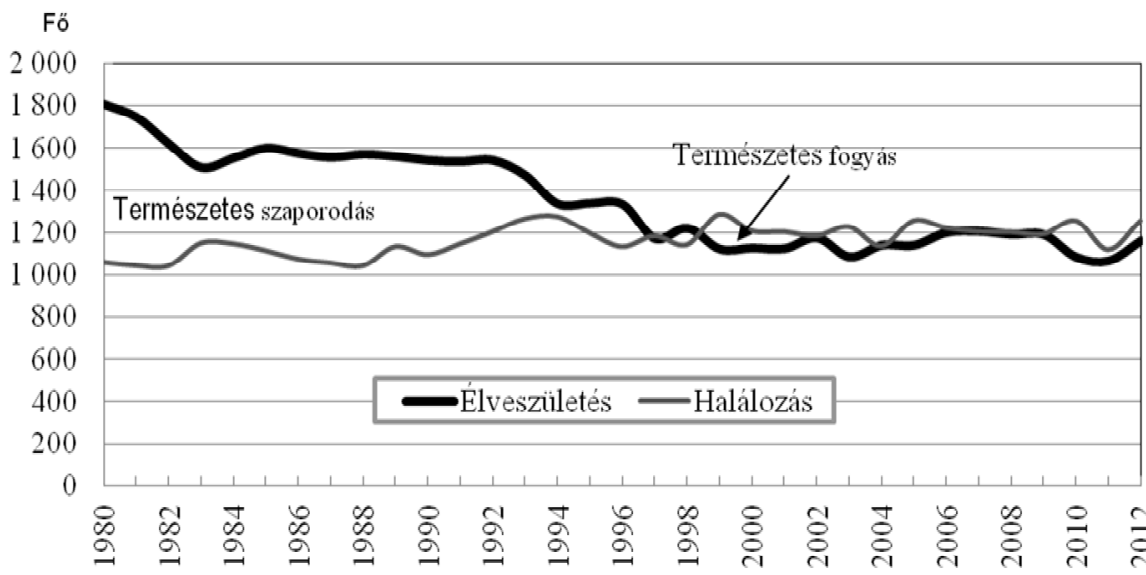

1. ábra

Az élveszületések és a halálozások száma Nyíregyházán.

Forrás: $\mathrm{KSH}^{1}$ ), saját szerkesztés.

A 2001. és a 2011. évi cenzus között Nyíregyháza az egyetlen olyan megyeszékhelye az országnak, ahol nem volt természetes fogyás. A többi megyeszékhellyel való összehasonlításban a migrációs egyenleg is a kedvezőbbek közé tartozik. A nagyvárosok sorában migrációs nyereséget 2001-2011 között Nyíregyháza mellett csupán a fóváros, továbbá a legnagyobb egyetemi városok közül Debrecen, Szeged, valamint Kecskemét, Eger és Győr mutatott. (2. ábra.)

A természetes népmozgalmi és a vándormozgalmi folyamatok erdőjeként Nyíregyházán (a már említett) szerény népességszám-növekedés alakult ki, miközben a többi megyeszékhely lakónépessége stagnált vagy csökkent, Kecskemét kivételével, amely egyébként a nyíregyházinál nagyobb ütemü népességszám-emelkedést realizált. 


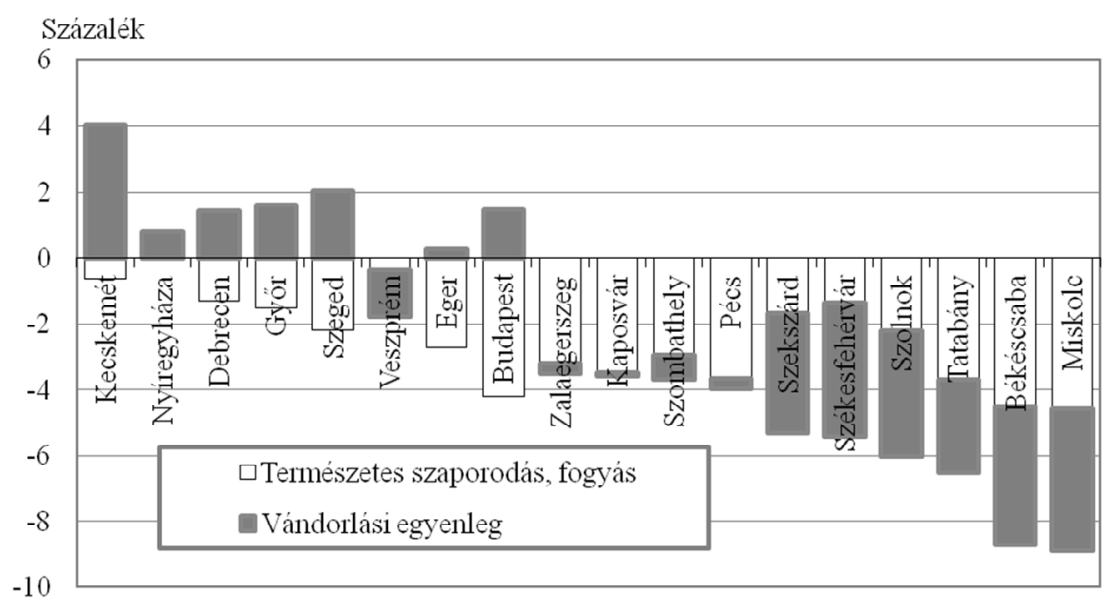

2. ábra

A lakónépesség számát alakító tényezők hatása 2001-2011 között a megyeszékhelyeken, a 2001. évi népességhez képest.

Forrás: $\mathrm{KSH}^{2}$ ), saját szerkesztés.

\section{Korszerkezet}

A városban élők korszerkezete tíz évenkénti léptékkel mérve jelentős változásokat mutat, egyrészt a Ratkó-korszak utóhatásaként megjelenő nagy létszámú korosztályok jelenléte, másrészt a születések számának szinte folyamatos csökkenése, továbbá az átlagéletkor emelkedése miatt. A korstruktúrára természetesen hatással van a vándormozgalom is. Így egy-egy korcsoportban a népességszám változása igen jelentős volt 2001-2011 között.

Az abortusztilalom miatt az 1953-1955 között, illetve ennek környékén született nagy létszámú korosztályok (Ratkó-gyerekek), illetve azok gyerekei (Ratkó-unokák) 2011-ben az 55-59 évesek, illetve a 35-39 évesek magas számában jelennek meg. (1. tábla.) Hasonló hatású a II. világháború után született nagy létszámú korosztályok képviselőinek jelenléte 2011-ben a 65-69 évesek között, illetve gyerekeik megjelenése a 30-34 évesek körében. A születéskor várható átlagéletkor emelkedéséből adódó elöregedés az időskorúakon belül föként a legidősebbek (80 év körüliek és a felettiek) igen jelentős számbeli növekedésével jár, miközben a 64 év felettiek valamennyi korcsoportja egyre számosabb. (1. tábla.)

Ugyanakkor a 30 év alatti korosztályba tartozók mind kevesebben vannak, összegfüggésben a születéseknek az adott időszakban bekövetkezett csökkenésével, és nem utolsósorban elvándorlásukkal. A fiatalok száma legnagyobb mér- 
tékben a 20-29 év közöttieknél csökkent, amiben jelentős szerepe van az elvándorlásoknak.

\begin{tabular}{|c|c|c|c|c|c|c|}
\hline \multirow[b]{2}{*}{$\begin{array}{c}\text { Korcso- } \\
\text { port, } \\
\text { éves }\end{array}$} & \multicolumn{2}{|c|}{ Férfiak } & \multicolumn{2}{|c|}{ Nők } & \multicolumn{2}{|c|}{ Összesen } \\
\hline & fö & $\begin{array}{l}\text { a 2001. évi } \\
\text { \%-ában }\end{array}$ & fö & $\begin{array}{l}\text { a } 2001 . \\
\text { évi } \\
\% \text {-ában }\end{array}$ & fö & 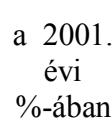 \\
\hline-4 & 2980 & 101,6 & 2846 & 103,9 & 5826 & 102,7 \\
\hline $5-9$ & 2973 & 85,9 & 2820 & 86,5 & 5793 & 86,1 \\
\hline $10-14$ & 3201 & 81,8 & 3090 & 78,2 & 6291 & 80,0 \\
\hline $15-19$ & 4312 & 83,8 & 4446 & 85,1 & 8758 & 84,5 \\
\hline $20-24$ & 3724 & 67,5 & 3803 & 64,7 & 7527 & 66,1 \\
\hline $25-29$ & 3663 & 72,2 & 3890 & 75,9 & 7553 & 74,0 \\
\hline $30-34$ & 4898 & 119,3 & 5127 & 121,0 & 10025 & 120,1 \\
\hline $35-39$ & 5320 & 155,9 & 5544 & 151,9 & 10864 & 153,9 \\
\hline $40-44$ & 4225 & 108,8 & 4604 & 97,2 & 8829 & 102,4 \\
\hline $45-49$ & 3351 & 74,1 & 3703 & 69,6 & 7054 & 71,7 \\
\hline $50-54$ & 3522 & 91,9 & 4524 & 106,0 & 8046 & 99,3 \\
\hline $55-59$ & 4081 & 153,9 & 5150 & 158,7 & 9231 & 156,5 \\
\hline $60-64$ & 3386 & 157,2 & 4246 & 142,5 & 7632 & 148,7 \\
\hline $65-69$ & 2221 & 121,8 & 3135 & 121,8 & 5356 & 121,8 \\
\hline $70-74$ & 1503 & 98,0 & 2609 & 109,7 & 4112 & 105,1 \\
\hline $75-79$ & 1104 & 108,6 & 2069 & 106,2 & 3173 & 107,0 \\
\hline $80-84$ & 670 & 158,8 & 1506 & 170,2 & 2176 & 166,5 \\
\hline $85-89$ & 295 & 181,0 & 827 & 152,6 & 1122 & 159,1 \\
\hline $90-94$ & 77 & 122,2 & 238 & 149,7 & 315 & 141,9 \\
\hline 95-99 & 11 & 78,6 & 44 & 115,8 & 55 & 105,8 \\
\hline $100-$ & 3 & 75,0 & 5 & 83,3 & 8 & 80,0 \\
\hline Összesen & 55520 & 99,8 & 64226 & 101,7 & 119746 & 100,8 \\
\hline
\end{tabular}

1. tábla

Nyíregyháza lakónépessége korcsoportonként nemek szerint, 2011.

Forrás: $\mathrm{KSH}^{3}$ ), saját szerkesztés.

A korcsoportok nagyobb aggregátumait képezve vizsgálhatók az ún. függőségi, eltartottsági ráták, melyek a felnőtt korú népességhez viszonyítva mutatják a gyermek, valamint az időskorúak, továbbá azok együttes számát. Ezen mutatók segítségével vizsgálhatók a felnőtt korúak társadalmi értelemben vett eltartási kötelezettsége. A gyermekkorú népesség tekintetében fennálló eltartási teher Nyíregyháza lakossága esetében is csökken, miközben az időseké emelkedik. Száz gyermekkorúra Nyíregyházán 91 időskorú jut (vagyis itt még több a gyermekkorú, mint az időskorú). A megyék sorában, országos viszonylatban is a legalacsonyabbnak számító Szabolcs-Szatmár-Bereg megyeinél azonban a nyíregyházi öregedési index magasabb. Mindazonáltal a megyei jogú városok sorá- 
ban a nyíregyházi mutató értéke a legkedvezőbb. A nyíregyházihoz hasonló ,jó” adatot csupán Kecskemét mutat.

A férfiak és a nők korszerkezete Nyíregyháza lakossága esetén is lényegesen eltér, döntően a két nem eltérő mortalitása miatt. A biológiai okokból adódó születéskori férfitöbblet a fiatal kor vége felé tünik el. Ennek oka a férfiak magasabb csecsemőhalálozási arányszáma és a fiatalkorúakat leginkább veszélyeztető ún. erőszakos halálozásokban (föként a közlekedési balesetekben) az erősebbik nem nagyobb érintettsége, továbbá az is, hogy a migrációban a férfiak részvétele valamivel intenzívebb, mint a nőké. Az életkor emelkedésével az életmód, életvitel miatti különbségek a férfiaknak a nőkénél lényegesen rosszabb mortalitását eredményez. A nemi arányt kifejező ún. feminitási mutató, az ezer férfira jutó nők száma egyre torzabb nemi arányt tükröz, különösen idősebb korban.

A nők korszerkezete az eltérő mortalitásból adódóan lényesen idősebb, mint a férfiaké (3. ábra). Más aspektusból ez azt jelenti, hogy az idősek (64 év felettiek) kétharmada, ezen belül a hetvenéves és idősebbek több mint héttizede nő.

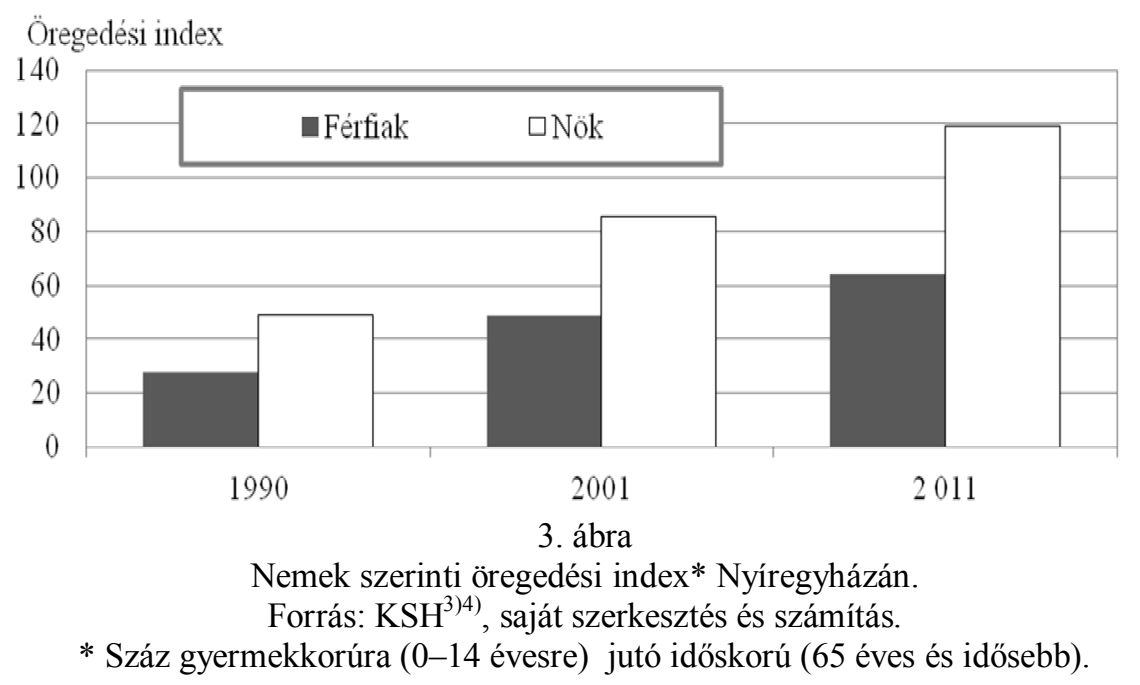

A nemenkénti öregedési index a megyeszékhely esetén az országos és a Szabolcs-Szatmár-Bereg megyei között alakul. Az országosnál mintegy 21-23\%-kal alacsonyabb a nők és férfiak öregedésének mértéke egyaránt, ugyanakkor a Szabolcs-Szatmár-Bereg megyeinek a nyíregyházi férfiak öregedési indexe 1,2szerese, a nőké pedig mintegy 1,5-szerese. 


\section{Családi állapot}

A népesség családi állapot szerinti struktúrája meglehetősen radikális változásokat mutat, melyek a nőtlen, hajadon családi állapotúak arányának számottevő emelkedését mutatják. E közben növekszik az özvegyek és az elváltak aránya is. Nyíregyházán az 1990. és a 2011. évi népszámlálás között a 15 éves és idősebb népességen belül a hajadonok aránya 24\%-ról 31\%-ra emelkedett, a házasoké 61\%-ról 47\%-ra csökkent. Az özvegyek és az elváltak egyaránt 10-12\% körüli részarányt képviseltek. A családi állapot szerinti struktúra átrendeződésével egyidejüleg terjed az élettársi kapcsolat. Az élettársi kapcsolatban élők döntő hányadát a fiataloknál a nőtlenek, hajadonok, az érettebb korúaknál pedig az elváltak adják.

\begin{tabular}{|c|c|c|c|c|c|c|c|c|}
\hline \multirow{2}{*}{$\begin{array}{c}\text { Kor- } \\
\text { csoport, éves }\end{array}$} & \multicolumn{2}{|c|}{ Hajadon, nötlen } & \multicolumn{2}{|c|}{ Házas } & \multicolumn{2}{c|}{ Özvegy } & \multicolumn{2}{c|}{ Elvált } \\
\cline { 2 - 9 } & fériak & nők & férfiak & nők & férfiak & nők & férfiak & nők \\
\hline $15-19$ & 100,0 & 99,8 & - & 0,2 & 0,0 & 0,0 & 0,0 & 0,0 \\
$20-24$ & 97,7 & 94,2 & 2,3 & 5,4 & 0,0 & 0,1 & 0,0 & 0,3 \\
$25-29$ & 80,9 & 63,2 & 17,8 & 33,5 & 0,0 & 0,1 & 1,3 & 3,2 \\
$30-34$ & 48,6 & 34,4 & 45,9 & 55,5 & 0,0 & 0,4 & 5,4 & 9,8 \\
$35-39$ & 28,3 & 20,0 & 60,7 & 60,9 & 0,1 & 0,8 & 11,0 & 18,2 \\
$40-44$ & 16,3 & 12,4 & 65,5 & 60,8 & 0,5 & 1,9 & 17,8 & 24,9 \\
$45-49$ & 11,2 & 8,0 & 68,8 & 62,0 & 1,1 & 4,8 & 18,8 & 25,1 \\
$50-54$ & 8,2 & 5,5 & 70,5 & 61,1 & 2,0 & 9,0 & 19,3 & 24,5 \\
$55-59$ & 5,8 & 4,7 & 73,9 & 59,2 & 3,3 & 14,6 & 17,1 & 21,6 \\
$60-64$ & 2,7 & 3,9 & 77,3 & 55,0 & 6,1 & 23,7 & 13,8 & 17,4 \\
$65-69$ & 2,3 & 4,1 & 81,7 & 48,2 & 7,7 & 34,6 & 8,3 & 13,1 \\
$70-74$ & 1,7 & 3,3 & 79,3 & 35,1 & 11,6 & 51,2 & 7,5 & 10,5 \\
$75-79$ & 3,2 & 3,3 & 74,4 & 24,7 & 17,4 & 64,2 & 5,1 & 7,8 \\
$80-84$ & 2,4 & 3,9 & 65,8 & 13,9 & 28,8 & 75,8 & 3,0 & 6,4 \\
$85-$ & 2,6 & 3,2 & 51,0 & 4,4 & 43,8 & 88,4 & 2,6 & 3,9 \\
\hline Összesen & 35,8 & 27,5 & 51,5 & 43,6 & 3,0 & 15,1 & 9,7 & 13,8 \\
\hline
\end{tabular}

2. tábla

A népesség családi állapot szerinti megoszlása Nyíregyházán korcsoportok szerint, 2011. Forrás: $\mathrm{KSH}^{5}$, saját szerkesztés és számítás. 
A nőtlen, hajadon forma térnyerését jól mutatja, hogy a 25-29 éveseknél arányuk a két legutóbbi népszámlálás között 43\%-ról 72\%-ra nőtt. Hasonlóan nagyfokú emelkedés figyelhető meg a 30-34 éveseknél, akik négytizede még hajadon vagy nőtlen volt 2011-ben. A házasság intézményének megítélése és azok stabilitása is kedvezőtlenebb a korábbinál. A nőknél minden korcsoportban nagyobb relatív gyakorisággal fordulnak elő az elváltak és az özvegyek is, mint a férfiaknál.

A családstruktúra az országoshoz képest a tradíciók nagyobb fokú továbbélését mutatja. A házasok részaránya valamennyi korcsoportban magasabb az országosnál, különösen a fiatalabbaknál. (A megyei átlaghoz viszonyítva azonban Nyíregyházán alacsonyabb a házasok aránya.) Ezzel egyidejüleg az elváltak is nagyobb gyakorisággal fordulnak elő az országosnál, ugyancsak valamennyi korcsoportban.

\section{Iskolázottsági szint}

Nyíregyháza lakosságának iskolázottsági színvonala számottevően javult a 2001-2011 közötti időszakban. Különösen figyelemre méltó a diplomások számának igen intenzív növekedése. Így a 25 éves és idősebb népességen belül a diplomások aránya 18\%-ról 27\%-ra emelkedett. A növekedés az országosnál jóval nagyobb intenzitású volt. A felsőfokú végzettségüek aránya a megyeszékhelyek sorában is a kedvezőbbek közé tartozik.

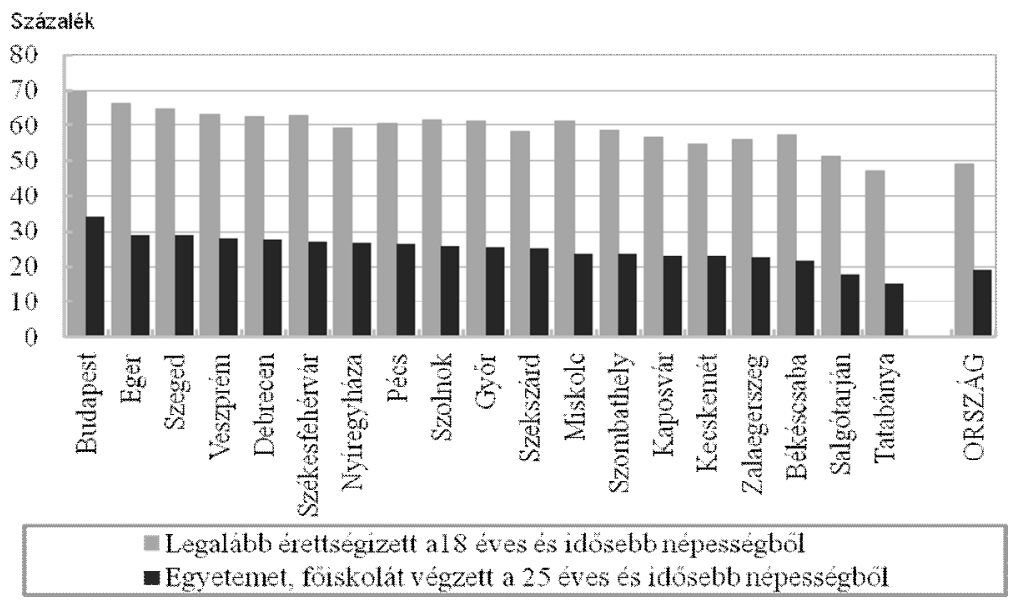

4. ábra. A legalább érettségivel és a felsőfokú végzettséggel rendelkezők aránya a megfelelő korú népességből,2011.

Forrás: $\mathrm{KSH}^{6}$, saját szerkesztés. 
Nagymértékben bővült az érettségizettek száma is. (A javulás e tekintetben szintén nagyobb volt, mint országosan.) Nyíregyháza 18 éves és idősebb népességének 59\%-át adták az érettségizett 2011-ben. E tekintetben azonban a város a megyeszékhelyek rangsorában a kedvezőtlenebb étéket mutatók közé tartozik. (4. ábra.)

A 15 éves és idősebb népesség csekély hányada, mindössze 3\%-a nem rendelkezik alapfokú végzettséggel. Ez az arány 1990-ben még 14\% volt. A 10 éves és idősebb népességből az általános iskola első osztályát sem elvégzők aránya (melyet, jobb nem lévén, az analfabéták részarányának mérésére is használnak) mindössze 0,5\% (1990-ben még 1\% feletti) volt.

Az igen dinamikus kedvező trendek mellett azonban vannak kedvezötlen jelenségek is. A generációváltásból adódó iskolázottsági szint javulással egyidejüleg a legkevésbé iskolázott réteg kisebb fokú újratermelődése is kimutatható a korcsoportonkénti iskolázottsági adatokból. A 10-14 évesek körében magasabb lett az általános iskola első osztályát sem elvégzők aránya, a 2001. évi 0,5\%-ról $0,8 \%$-ra emelkedett.

\begin{tabular}{|c|c|c|c|c|c|c|c|c|c|c|c|c|}
\hline \multirow{3}{*}{$\begin{array}{l}\text { Korcso- } \\
\text { port, } \\
\text { éves }\end{array}$} & \multicolumn{3}{|c|}{$\begin{array}{l}\text { Az általános iskola első } \\
\text { évfolyamát sem végez- } \\
\text { te el }\end{array}$} & \multicolumn{3}{|c|}{$\begin{array}{l}\text { Legalább általános } \\
\text { iskola } 8 \text {. évfolyam }\end{array}$} & \multicolumn{3}{|c|}{ Legalább érettségi } & \multicolumn{3}{|c|}{$\begin{array}{c}\text { Egyetem, föiskola stb } \\
\text { oklevéllel }\end{array}$} \\
\hline & férfi & nő & $\begin{array}{l}\text { össze- } \\
\text { sen }\end{array}$ & férfi & nő & $\begin{array}{l}\text { össze- } \\
\text { sen }\end{array}$ & férfi & nö & $\begin{array}{c}\text { össze- } \\
\text { sen }\end{array}$ & férfi & nő & $\begin{array}{c}\text { össze- } \\
\text { sen }\end{array}$ \\
\hline & \multicolumn{12}{|c|}{ az adott korcsoport \%-ában } \\
\hline $7-9$ & 25,6 & 24,4 & 25,0 & - & - & - & - & - & - & - & - & - \\
\hline $10-14$ & 0,6 & 1,0 & 0,8 & 9,7 & 10,5 & 10,1 & - & - & - & - & - & - \\
\hline $15-19$ & 0,1 & 0,3 & 0,2 & 97,9 & 98,6 & 98,2 & 17,6 & 20,4 & 19,0 & - & - & - \\
\hline $20-24$ & 0,2 & 0,7 & 0,5 & 99,2 & 99,0 & 99,1 & 73,1 & 83,4 & 78,3 & 7,7 & 16,8 & 12,3 \\
\hline $25-29$ & 0,4 & 0,6 & 0,5 & 99,1 & 98,8 & 99,0 & 69,2 & 81,7 & 75,7 & 28,6 & 48,9 & 39,0 \\
\hline $30-34$ & 0,4 & 0,8 & 0,6 & 99,1 & 98,7 & 98,9 & 60,4 & 75,6 & 68,2 & 30,6 & 44,5 & 37,7 \\
\hline $35-39$ & 0,2 & 0,6 & 0,4 & 99,2 & 98,9 & 99,0 & 53,6 & 71,4 & 62,7 & 25,9 & 38,4 & 32,3 \\
\hline $40-44$ & 0,3 & 0,4 & 0,4 & 99,2 & 98,8 & 99,0 & 51,3 & 70,4 & 61,3 & 22,7 & 33,1 & 28,1 \\
\hline $45-49$ & 0,1 & 0,5 & 0,3 & 99,4 & 98,9 & 99,1 & 52,6 & 67,7 & 60,5 & 25,1 & 31,5 & 28,5 \\
\hline $50-54$ & 0,3 & 0,4 & 0,3 & 99,1 & 98,7 & 98,9 & 50,1 & 62,4 & 57,0 & 22,7 & 25,3 & 24,1 \\
\hline $55-59$ & 0,1 & 0,4 & 0,3 & 99,3 & 98,9 & 99,1 & 48,6 & 58,1 & 53,9 & 21,4 & 20,4 & 20,8 \\
\hline $60-64$ & 0,3 & 0,4 & 0,4 & 99,0 & 99,0 & 99,0 & 53,7 & 59,1 & 56,7 & 22,4 & 18,1 & 20,0 \\
\hline $65-69$ & 0,4 & 0,4 & 0,4 & 98,2 & 97,5 & 97,8 & 54,4 & 53,3 & 53,7 & 26,5 & 19,0 & 22,1 \\
\hline $70-74$ & 0,3 & 0,7 & 0,6 & 96,6 & 92,0 & 93,7 & 48,5 & 37,9 & 41,8 & 24,2 & 10,8 & 15,7 \\
\hline $75-79$ & 1,2 & 2,2 & 1,9 & 92,8 & 77,0 & 82,5 & 47,8 & 30,8 & 36,7 & 25,5 & 8,2 & 14,2 \\
\hline $80-84$ & 1,5 & 2,5 & 2,2 & 87,5 & 66,1 & 72,7 & 43,3 & 19,5 & 26,8 & 22,2 & 5,6 & 10,8 \\
\hline $85-$ & 1,3 & 3,6 & 3,0 & 81,9 & 49,0 & 57,5 & 38,9 & 12,7 & 19,5 & 17,4 & 3,9 & 7,4 \\
\hline összesen & 1,2 & 1,4 & 1,3 & 89,6 & 88,6 & 89,1 & 47,2 & 54,6 & 51,2 & 19,3 & 22,9 & 21,2 \\
\hline
\end{tabular}

3. tábla. Nyíregyháza lakónépességének iskolázottsági szintje korcsoportonként, nemek szerint, 2011.

Forrás: $\mathrm{KSH}^{6}$, saját szerkesztés. 
Az egyetemet végzettek aránya a 25-29, illetve a 30-34 éveseknél gyakorlatilag megduplázódott, 40\% körülire emelkedett 2001-2011 között. Mindez a felsőfokú oktatás 2000-es évekre jellemző, a korábbiaknál lényegesen nagyobb fokú expanzióját jelzi. Az életkor emelkedésével a diplomások aránya mérséklődik, mindazonáltal valamennyi korcsoportban kedvezőbb a korábbiaknál a generációváltások hatásaként. (3. tábla.)

A Nyírség fővárosában zajló fejlődést jól mutatja, hogy a 25-29 évesek körében a diplomások aránya a megyeszékhelyeket tekintve Budapest, Szeged és Debrecen után Nyíregyházán a legmagasabb, és a 30-34 évesek, valamint a 3539 évesek esetén is dobogós, illetve ahhoz közeli magas arány jellemző.

Az iskolázottsági szint tekintetében jelentős átrendeződés zajlik nemek szerint. Az 55 év alatti korcsoportokban a nők iskolázottsága rendre kedvezőbb, jelezve a föiskolai, egyetemi végzettséghez kötött szakmák néhány évtizede tartó, és egyre intenzívebb elnőiesedését. Az 55 éves kor felett azonban a férfiak körében magasabb a diplomások aránya, a korábbi tradícióknak megfelelően. A diplomások aránya a 25-29 éves nők körében 1,7-szerese az azonos korú férfiakénak. A 30-34 és a 35-39 éveseknél is hasonlóan magas, 1,5-szeres az eltérés. A diploma megléte napjainkban jelentős jövedelem-differenciáló tényező. Ugyanakkor a középfokú szakmai végzettség iránti kereslet is növekszik, ami jó egzisztencia kialakítását teszi lehetővé, és ez elsősorban a férfiak számára vonzó lehetőség. A szakma megszerzésé mellett ez a réteg jellemzően érettségit is szerez.

Az érettségi megléte tekintetében a férfiakkal szemben ugyancsak meglévő női előny (ami csak a 70 év felettieknél tünik el) ugyanakkor némileg mérséklödött a 2000-es években. A legmagasabb iskolai végzettségként érettségivel rendelkezők aránya mind két nemnél valamennyi korcsoportban javult, és a javulás a férfiaknál volt erőteljesebb.

\section{Nemzetiségek}

A 13 hivatalos hazai nemzetiség mindegyike képviselteti magát Nyíregyháza népességében, igen eltérő számban. A 6-8 fös horvát, szlovén nemzetiségtől a 23-108 fös szerb, görög, örmény, bolgár, lengyel, ruszin, illetve a néhány vagy több száz fös szlovák, román, ukrán, német nemzetiségüeken át egészen a több mint 2000 fös cigányságig. Így összesen 4,2 ezer fó vallotta magát legalább egy szempont (úgymint identitás, anyanyelv, családi baráti közösségben használt nyelv) alapján valamelyik hazai nemzetiséghez tartozónak. Ez a város népességének mindössze 3,5\%-a.

A megyeszékhelyen mérsékelt a - hazai nemzetiségek sorában kiugróan legnagyobb létszámú - cigányság jelenléte, így a város összességében a nemzetisé- 
giek által relatíve ritkán lakott területnek tekinthető. Szabolcs-Szatmár-Bereg ugyanakkor a nemzetiségiek által legsürübben lakott területe az országnak, az itt élő romák nagy száma miatt, akik a hazai cigány lakosság 14\%-át jelentik.

A megyében élő kis lélekszámú nemzetiségiek jelentős része koncentrálódik a megyeszékhelyre. A lengyelek kétharmada, a szlovákok, szlovének hétnyolctizede nyíregyházi, de a többi nemzetiség esetén is - kivéve a németeket, románokat, horvátokat - jellemzően 30-40\% közötti, illetve a feletti megyén belüli részarányt mutat a város, miközben Nyíregyháza teljes népessége a megyében élők 21,4\%-át adja. (4. tábla.) Országos összevetésben is kiemelkedő az itt élő ruszinok és ukránok száma. Ezen hazai nemzetiség tagjainak 3, illetve 6\%-a él Nyíregyházán.

\begin{tabular}{|c|c|c|c|c|c|}
\hline \multirow[t]{2}{*}{$\begin{array}{c}\text { Hazai } \\
\text { nemzetiség }\end{array}$} & $\begin{array}{l}\text { Nemzeti- } \\
\text { ség }\end{array}$ & Anyanyelv & $\begin{array}{l}\text { Családi, baráti } \\
\text { közösség-ben } \\
\text { beszélt nyelv }\end{array}$ & $\begin{array}{r}\text { Nemze } \\
\text { (aze } \\
\text { legaláb }\end{array}$ & $\begin{array}{l}\text { ghez tartozó } \\
\text { zesen } \\
\text { i háromból } \\
\text { sy szempont- } \\
\text { ól) }\end{array}$ \\
\hline & \multicolumn{4}{|c|}{ fó } & $\begin{array}{l}\text { arány a me- } \\
\text { gyeiből, \% }\end{array}$ \\
\hline Bolgár & 28 & 31 & 20 & 63 & 36,8 \\
\hline Cigảny & 2177 & 214 & 225 & 2208 & 4,9 \\
\hline Görög & 19 & 1 & 13 & 30 & 43,5 \\
\hline Horvăth & 3 & - & 4 & 6 & 25,0 \\
\hline Lengyel & 78 & 19 & 29 & 86 & 65,6 \\
\hline Német & 317 & 77 & 336 & 613 & 21,9 \\
\hline Ormény & 32 & 16 & 10 & 35 & 36,1 \\
\hline Román & 239 & 148 & 184 & 305 & 25,0 \\
\hline Ruszin & 85 & 32 & 53 & 108 & 28,9 \\
\hline Szerb & 15 & 8 & 13 & 23 & 48,9 \\
\hline Szlovák & 189 & 37 & 54 & 214 & 72,1 \\
\hline Szlovén & 6 & 4 & 4 & 8 & 80,0 \\
\hline Ukrán & 354 & 230 & 273 & 465 & 31,8 \\
\hline összesen & 3542 & 817 & 1218 & 4164 & 8,1 \\
\hline
\end{tabular}

4. tábla. A Nyíregyházán élő nemzetiségiek száma és aránya a megyében élő nemzetiségiekből, 2011.

Forrás: $\mathrm{KSH}^{7}$, saját szerkesztés.

Az ország legnagyobb, 315 ezer fớt meghaladó cigány nemzetiségéből 2,2 ezer fő él Nyíregyházán, és városban is kiemelkedően ez számít a legnagyobb lélekszámú nemzetiségnek (relatíve mérsékelt jelenléte ellenére).

A két legutóbbi népszámlálás között országosan és a megyében egyaránt 1,5szeresére nőtt a nemzetiségiek száma. A növekedésen belül azonban nem tudjuk mennyi volt az identitás javulásából, a kérdésfeltevés változásából (dupla kérdés, rákérdezés a másodsorban való hovatartozásra), illetve a népmozgalmi, vándormozgalmi folyamatokból adódó változás. 
A nemzetiségiek jelentős része, országosan hattizede vallotta meg valamelyik hazai nemzetiséghez való tartozását a másodsorban való hovatartozásra vonatkozó kérdésnél. A 2011. évi népszámláláskor jelentős civil mozgalom is segítette a nemzetiségiek minél pontosabb számbavételét. A 2001. és 2011. évi cenzusok között legtöbb hazai nemzetiség száma igen jelentősen bővült, ezen belül a cigányságé országosan 1,5-szeresére, a megyében 1,7-szeresére, Nyíregyházán kétszeresére nőtt.

A cigány népesség iskolázottsági, foglalkozási jellemzőik lényegesen kedvezőtlenebbek az átlagosnál, melyek az életkörülményeket is nagyban befolyásolják. Ugyanakkor a cigány nemzetiségüeknél is érzékelhető az iskolázottsági szint növekedése. Az általános iskola 8. osztályát befejezők aránya említésre méltóan javult, és az ennél magasabb végzettséggel rendelkezők részaránya ugyancsak magasabb lett a korábbinál.

\section{Vallás}

A vallási hovatartozás nem tartozik a népszámlálás kötelezően megválaszolandó kérdései közé, hasonlóan a nemzetiségre, illetve a fogyatékosságra vonatkozó kérdéskörhöz. A népszámlálások történetében az 1949 után első alkalommal az 2001. évinél került sor a vallási hovatartozásra való rákérdezésre. A 2001 és 2011. évi adatok összehasonlításánál figyelembe kell venni, hogy különbözött a kérdésfeltevés. 2001-ben a „Vallása, felekezete?” kérdésre, 2011-ben „A melyik vallási közösséghez, felekezethez tartozónak érezi magát?" kérdésre kellett válaszolni. Számos tényező mellett - melyek hatásának feltérképezése célirányos kutatást igényel - a kérdésfeltevés változása is hatással lehetett arra, hogy a vallási közösséghez, felekezethez tartozásról nem nyilatkozók aránya a 2001. évi $1 \%$ körüli értékről 2001-re 26\%-ra nőtt Nyíregyházán, hasonlóan az országoshoz. A nem nyilatkozók mellett a korábbinál többen voltak azok is, akik semmilyen vallási közösséghez, felekezethez tartozónak nem érezték magukat. Népességen belüli részarányuk 12-13\%-ról 15\%-ra emelkedett. Ez az arány a megyeinél lényegesen magasabb, az országos átlagtól azonban elmarad.

2011-ben Nyíregyháza lakosságának 59\%-a jelezte valamelyik vallási közösséghez tartozását. Ezen belül 21\%-ot a római katolikusok 16\%-ot a reformátusok, 11\%-ot a görög katolikusok, 7\%-ot az evangélikusok, 4\%-ot az elöbbieken kívüli vallási közösséghez, felekezethez tartozók képviseltek.

Nyíregyháza lakossága a megye egészére jellemzőtől lényegesen eltérő vallási struktúrát mutat, ami elsősorban a református vallásúak kisebb arányában, illetve ezzel egyidejüleg a görög katolikusok, az evangélikusok és a kisebb vallási közösségekhez tartozók magas arányában mutatkozik meg. 


\section{Gazdasági aktivitás}

Nyíregyháza lakosságának gazdasági aktivitása a két legutóbbi népszámlálás között jelentősen javult, azonban az 1990. évi szintet a kedvező változások ellenére sem érte el. Az 1990. év eleji foglalkoztatási színvonalat a rendszerváltás előttivel azonosíthatjuk, hiszen az átalakuláshoz kapcsolódó folyamatok ezt követően okoztak robbanásszerü változásokat. A 2001. évi népszámlálási adatok a 1990-es évek közepére jellemző mélypont utáni, majd egy rövid 1997-1998-tól kezdődő javuló periódus utáni állapotot tükröznek. A 2001-2011 közötti változások már a gazdaság egy tartós növekedési szakaszának munkaerő-piaci hatását mutatják. A növekedési periódus azonban 2006-tól a belső fogyasztás visszaszorítására irányuló egyensúlyjavító intézkedések, majd a 2008 második felétől a gazdasági és pénzügyi válság hatására megtört, és az ismételt élénkülés csupán 2010-tól indult meg.

2011-ben Nyíregyháza teljes lakosságának 41\%-a volt foglalkoztatott és $6 \%$ munkanélküli. (5. tábla.) E két gazdaságilag aktív kategóriába tartozók bővülésével egyidejüleg szükült az inaktívak réteg, mind a főként nyugdíjasokból álló inaktív keresők, mind az eltartottak népességen belüli aránya kisebb, egyaránt $26-27 \%$ lett.

\begin{tabular}{|c|c|c|c|c|c|c|c|}
\hline \multirow{2}{*}{$\begin{array}{l}\text { Gazdasági aktivi- } \\
\text { tás }\end{array}$} & \multicolumn{3}{|c|}{ Fö } & \multicolumn{3}{|c|}{ Megoszlás,\% } & \multirow{2}{*}{$\begin{array}{l}\text { 2011. évi a } \\
\text { 2001. évi } \\
\% \text {-ában }\end{array}$} \\
\hline & 1990 & 2001 & 2011 & 1990 & 2001 & 2011 & \\
\hline Fog & 49535 & 44230 & 48548 & 43,4 & 37,2 & 40,5 & 109,8 \\
\hline Munkanélküli & 1685 & 5345 & 7583 & 1,5 & 4,5 & 6,3 & 141,9 \\
\hline Inaktív kereső & 22846 & 32634 & 30996 & 20,0 & 27,5 & 25,9 & 95,0 \\
\hline Eltartott & 40086 & 35586 & 32619 & 35,1 & 30,0 & 27,2 & 91,7 \\
\hline összesen & 114152 & 118795 & 119746 & 100,0 & 100,0 & 100,0 & 100,8 \\
\hline
\end{tabular}

5. tábla

Nyíregyháza lakónépessége gazdasági aktivitás szerint.

Forrás: $\mathrm{KSH}^{8) 9}$, saját szerkesztés és számítás.

A város lakosságának gazdasági aktivitás szerinti összetétele az országoshoz igen hasonló struktúrát mutat, a munkanélküliség azonban a nagyvárosi lét ellenére valamivel magasabb szintü az átlagosnál. Nyíregyháza lakosságának fiatalos korszerkezete miatt ugyanis sokan vannak azok is, akik munkaerejüket kínálják ugyan a munkaerőpiacon, azonban az nem találkozik a kereslettel, strukturális okokból vagy túlkínálat miatt.

A megye egészére jellemzőnél a megyeszékhely lakosságának aktivitása lényegesen kedvezőbb, ami föként a magasabb foglakoztatási arányban mutatkozik meg. A magasabb foglalkoztatási arányához nagyban hozzájárul, hogy a 
foglalkoztatási szempontból legaktívabb (legmagasabb foglalkoztatási aránnyal jellemezhető) 30-59 éves korcsoport népességi aránya számottevő, az országosnál is magasabb.

A fiatalok - 29 év alattiak - foglalkoztatási rátája nem éri el országos átlagot. Ezzel egyidejüleg az ezen a korosztályra egyébként is jellemző igen magas munkanélküliségi ráta jóval az országos felett alakul. Ugyanakkor az idősebb korú munkavállalók foglalkoztatása jól érzékelhetően magasabb az átlagosnál.

A férfiak foglalkoztatási színvonala változatlanul jobb, mint a nőké. Főleg a 40 év alattiaknál jellemző a férfiak javára mutatkozó eltérés, ami összefüggésben van a nők felsőoktatásban való, kiterjedtebb részvételével (6. tábla). A két nem közötti különbség az időskorúaknál is jelentős, amit részben a nyugdíjba vonulás eltérő lehetőségei, másrészt mentalitásbeli különbségek magyaráznak.

\begin{tabular}{|c|c|c|c|c|c|c|c|c|c|}
\hline \multirow{2}{*}{ Megnevezés } & $15-19$ & $20-29$ & $30-39$ & $40-49$ & $50-59$ & $60-69$ & $70-74$ & $75-$ & \multirow{2}{*}{ összesen } \\
\hline & \multicolumn{8}{|c|}{ éves } & \\
\hline \multicolumn{10}{|c|}{ Foglalkoztatási arány, \% } \\
\hline Férfiak & 2,1 & 53,8 & 82,9 & 79,8 & 66,4 & 18,5 & 6,5 & 1,4 & 44,7 \\
\hline Nök & 1,3 & 46,1 & 66,3 & 76,6 & 61,1 & 10,0 & 1,8 & 0,3 & 37,0 \\
\hline összesen & 1,7 & 49,9 & 74,4 & 78,1 & 63,5 & 13,6 & 3,5 & 0,7 & 40,5 \\
\hline \multicolumn{10}{|c|}{ Munkanélküliségi ráta, \% } \\
\hline Férfiak & 33,6 & 19,9 & 11,7 & 11,9 & 11,4 & 5,9 & 1,0 & - & 12,9 \\
\hline Nök & 40,4 & 22,0 & 14,4 & 12,8 & 10,6 & 5,2 & - & - & 14,1 \\
\hline összesen & 36,5 & 20,9 & 12,9 & 12,3 & 11,0 & 5,6 & 0,7 & - & 13,5 \\
\hline
\end{tabular}

\section{6. tábla}

A 15 éves és idősebb népesség foglalkoztatási arány Nyíregyházán korcsoportonként nemek szerint, 2011. Forrás: $\mathrm{KSH}^{10)}$, saját szerkesztés és számítás.

A város férfi lakosságának foglalkoztatása valamennyi korcsoportban alacsonyabb szintü a férfiak országos átlagnál, a nők viszont a 30 évesek korcsoportjától a városban dolgoznak nagyobb arányban. A fiatalok alacsony foglakoztatási szintjével összefüggésben a korosztály munkanélküliségének mértéke jóval az országos átlagot meghaladó. Az idősebb munkavállalóknál pedig a magasabb foglalkoztatási ráta ellenére alig kedvezőbb a munkanélküliség szintje az átlagosnál.

A megyeszékhelyekkel való összehasonlításban a Nyírség fővárosának foglalkoztatási színvonala viszonylag a kedvezőtlenebbek közé tartozik, és ezzel egyidejüleg a munkanélküliség a legmagasabbak között van. (5. ábra.) A Dunától keletre fekvő városok közül ugyanakkor csak a jelentős jármügyártási központként funkcionáló Kecskemét, az erősen iparosodott Szolnok, valamint Sze- 
ged foglalkoztatási színvonala kedvezőbb a városénál, miközben olyan nagyvárosoké alacsonyabb a nyíregyházinál, mint Pécs, Debrecen, és Miskolc.

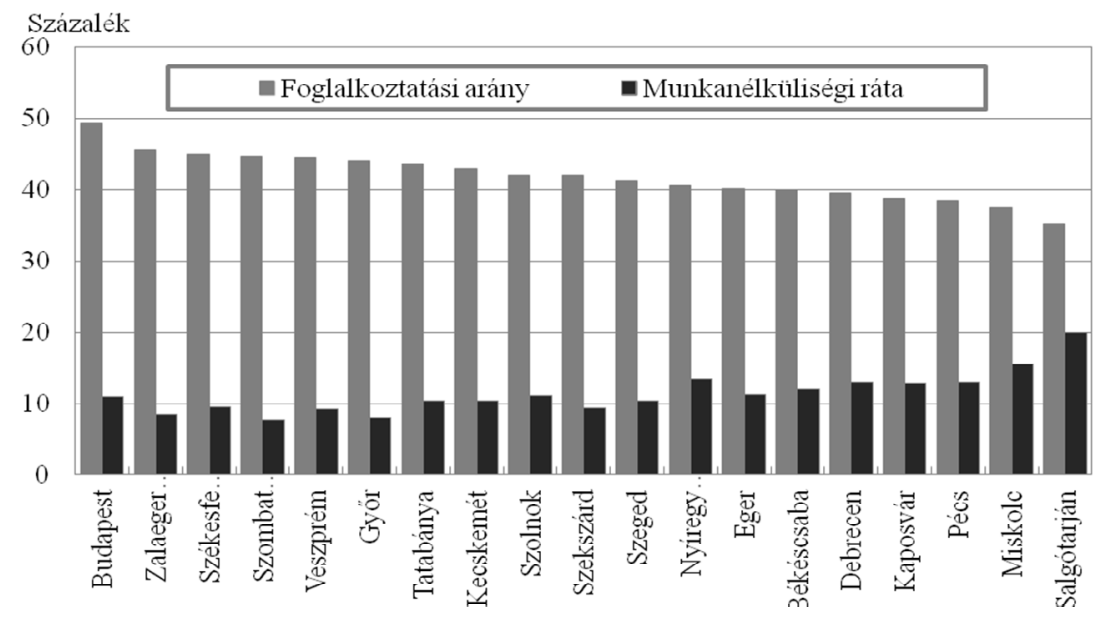

5. ábra. Foglalkoztatási arány, munkanélküliségi ráta megyeszékhelyek szerint, 2011 (a foglalkoztatási arány csökkenő rangsora szerint).

Forrás: $\mathrm{KSH}^{11)}$, saját szerkesztés és számítás.

A munkanélküliség szintje Salgótarján és Miskolc után a harmadik legmagasabb, valamivel meghaladva Debrecen, Kaposvár és Pécs lakosságának munkanélküliségi szintjét is.

\section{Háztartási, családi jellemzők}

A két legutóbbi népszámlálás között folytatódott a háztartások számának növekedése, nagymértékben emelkedett ugyanis az egyszemélyes háztartások, valamint egyszülős családok előfordulása. Ezek a változások a házaspári kapcsolaton alapuló háztartások rovására következtek be. A házaspári kapcsolaton alapuló háztartások számát mérsékelte az élettársi kapcsolatok bővülése is. A korábbinál kisebb gyakoriságúvá vált a családok együttélése. A változások dinamikáját jól mutatja, hogy mind az egyszemélyes, mind az egyszülös háztartások száma 1,4szeresére bővült a városban 2001-2011 között. (7. tábla.) A változások a háztartások struktúráját nagymértékben módosították, melyek az elaprózódás irányába hatottak. Nyíregyháza háztartásainak összetétele a kedvezőtlen változások ellenére számos vonatkozásban jobb az országosnál. Mérsékeltebb az egyedülállók aránya, kisebb súlyú az élettársi kapcsolat, jelentősebb a házaspári kapcsola- 
tok szerepe. Ugyanakkor az egyszülős háztartások aránya magasabb az országosnál.

\begin{tabular}{|c|c|c|c|c|c|c|c|c|}
\hline \multirow[b]{2}{*}{$\begin{array}{l}\text { Megneve- } \\
\text { zés }\end{array}$} & \multicolumn{4}{|c|}{ Egy családból álló háztartás } & \multirow{2}{*}{$\begin{array}{l}\text { Több csa- } \\
\text { ládból álló } \\
\text { ház-tartás }\end{array}$} & \multicolumn{2}{|c|}{$\begin{array}{l}\text { Nem családháztar- } \\
\text { tás }\end{array}$} & \multirow[b]{2}{*}{$\begin{array}{c}\text { össze- } \\
\text { sen }\end{array}$} \\
\hline & $\begin{array}{l}\text { házas- } \\
\text { pár }\end{array}$ & $\begin{array}{c}\text { élet- } \\
\text { társi } \\
\text { kapcso- } \\
\text { lat }\end{array}$ & $\begin{array}{l}\text { egy } \\
\text { szülo” } \\
\text { gyer- } \\
\text { mek- } \\
\text { kel }\end{array}$ & együtt & & $\begin{array}{l}\text { össze- } \\
\text { sen }\end{array}$ & $\begin{array}{l}\text { ebböl: } \\
\text { egyedül- } \\
\text { álló }\end{array}$ & \\
\hline Háztartás & 22110 & 3148 & 6574 & 31832 & 463 & 15667 & 14296 & 47962 \\
\hline $\begin{array}{l}\text { A } 2001 . \\
\text { évi } \\
\% \text {-ában }\end{array}$ & 94,8 & 142,8 & 140,6 & 105,4 & 37,4 & 142,7 & 143,4 & 113,1 \\
\hline
\end{tabular}

7. tábla

A háztartások száma Nyíregyházán háztartástípusok szerint, 2011.

Forrás: $\mathrm{KSH}^{12) 13)}$, saját szerkesztés és számítás.

Háztartást az egy fedél alatt élők alkotnak, akik a háztartásvitel részesei, a költségek tekintetében is. Így pl. a házaspárok, illetve azok gyermekei mellett az adott háztartáshoz tartoznak a családdal élő rokon személyek is, közös háztartásvitel esetén.

A család fogalma szigorúbb, hiszen ennél már a vérségi kapcsolat is feltétel, vagyis abba a családdal élő rokon személyek már nem tartoznak bele. Családot alkotnak a házaspárok, az élettársi kapcsolatban élők gyermekkel vagy a nélkül, továbbá a gyermekét egyedül nevelö szülő a gyermekkel.

\begin{tabular}{|c|c|c|c|c|c|}
\hline \multirow{2}{*}{ Megnevezés } & \multirow{2}{*}{ Házaspár } & \multirow{2}{*}{$\begin{array}{c}\text { Élettársi } \\
\text { kapcsolat }\end{array}$} & Apa & Anya & \multirow{2}{*}{ Összesen } \\
\hline & & & \multicolumn{2}{|c|}{ gyermekkel } & \\
\hline Család & 22788 & 3334 & 644 & 6012 & 32778 \\
\hline A 2001. évi \%-ában & 90,1 & 151,2 & 132,2 & 126,8 & 100,1 \\
\hline
\end{tabular}

8. tábla.

A családok száma Nyíregyházán családtípusonként, 2011

Forrás: $\mathrm{KSH}^{14) 15}$, saját szerkesztés és számítás.

A családok száma a két legutóbbi népszámlálás között alig változott Nyíregyházán (8. tábla). Ugyanakkor az egyszülős családok száma 1,3-szeresére, az élettársi kapcsolaton alapulóké 1,5-szerésre nőtt. Együttes bővülésük volumene azonban akkora volt, amennyivel a házaspáros családok száma csökkent. Nyíregyházán az élettársi kapcsolatok kisebb ütemben bővültek, mint országosan. Az egyszülős családok számának bővülése viszont intenzívebb volt az átlagosnál. A 
házaspáros családok gyakorisága így az országosnál valamivel nagyobb ütemben esett vissza, mindazonáltal a családstruktúrán belüli jelentőségük továbbra is nagyobb maradt az országosnál.

\section{Összegzés}

A kedvezőtlen demográfia folyamatok, mindenekelött a születések számának csökkenése, a családromboló folyamatok Nyíregyháza lakosságának demográfiai jellemzőit is kedvezőtlen irányba befolyásolták, és a folyamatok intenzitása számos esetben meghaladta az országost.

A születések és halálozások egyenlege csupán az utóbbi évektől mutat permanens hiányt. Ezzel egyidejüleg mérsékelt nyereséget jeleznek a vándormozgalmi folyamatok, melynek forrása a külföldi vándormozgalom.

A lakosság korösszetétele a felnőtt korúak viszonylag magas arányát mutatja, miközben az időskorúaké az átlagosnál alacsonyabb. Mindez kedvezően befolyásolja a népesség társadalmi értelemben vett eltartási kötelezettségét. Ugyanakkor a városban is fokozódik a népesség elöregedése.

A családi állapot szerinti struktúra változása követi az általános trendet, öszszefüggésben a házasság intézményének egyre kedvezötlenebb megítélésével, stabilitásának csökkenésével. Mindazonáltal a nőtlenek, hajadonok részaránya alacsonyabb az átlagosnál, a házasoké pedig magasabb. Ezzel együtt az elváltak súlya átlag feletti.

A népesség iskolázottsági szintje igen figyelemre méltóan javult. A változások dinamikáját jól mutatja, hogy a 25-29 évesek körében a diplomások aránya a megyeszékhelyeket tekintve Budapest, Szeged és Debrecen után a legmagasabb.

A lakosság gazdasági aktivitás szerinti szerkezete a megyeszékhelyekkel való összehasonlításban magas szintủ munkanélküliséget jelez, és a kedvezötlenebbek közé tartozik a foglalkoztatási ráta is, mindazonáltal a foglalkoztatási színvonal olyan nagyvárosokénál jobb, mint Debrecen, Pécs, Miskolc.

A háztartási, családi jellemzők a tradíciók változatlanul nagyobb szerepét mutatják a városban, ugyanakkor intenzíven zajlanak azok a folyamatok (pl. az egyedülállók táborának bővülése), melyek a háztartások elaprózódásához, a párkapcsolatok szerepének zsugorodásához vezetnek, és az egyszülős családok aránya a válások magas száma miatt átlag feletti. 


\section{Felhasznált irodalom}

1. www.ksh.hu/Adatok/Tájékoztatási adatbázis/Területi statisztika/Éves településszintű adatok 2012-es szerkezetben.

2. Waffenschmidt J. (szerk,) (2013) 2011. évi népszámlálás - Területi adatok 3.1-3.20. kötete, Budapest, Központi Statisztikai Hivatal.

3. www.ksh.hu/Adatgyüjtések/Népszámlálás, mikrocenzus/Kiadványok/Országos és területi adatok/2011. évi népszámlálás - Területi adatok - 3.1-3.20 kötetek Táblázatok 4.1.1.1., 4.1.1.2. táblái.

4. Csizmazia T., Kissné M. M. és Malakucziné P. M. (2013) 2011. évi népszámlálás - Területi adatok - 3.16. Szabolcs-Szatmár-Bereg, Budapest, Központi Statisztikai Hivatal.

5. www.ksh.hu/Adatgyüjtések/Népszámlálás, mikrocenzus/Kiadványok/Országos és területi adatok/2011. évi népszámlálás - Területi adatok - 3.16. kötet, Táblázatok, 3.1.1.1. tábla.

6. Szücs Z. (szerk,) (2003) 2001. évi népszámlálás - 6. Területi adatok - 6.16. Szabolcs-Szatmár-Bereg, Budapest, Központi Statisztikai Hivatal.

7. www.ksh.hu/Adatgyüjtések/Népszámlálás, mikrocenzus/Korábbi népszámlálások/Népszámlálás 2001/A 2001. évi népszámlálás kiadványai és adatai/ 6. Területi adatok/Táblázatok/Szabolcs-Szatmár-Bereg/3. településtípusonkénti adatok/3.11 tábla.

8. www.ksh.hu/Adatgyüjtések/Népszámlálás, mikrocenzus/Kiadványok/Országos és területi adatok/2011. évi népszámlálás - Területi adatok - 3.16. kötet, Táblázatok, 3.1.3.1. tábla.

9. www.ksh.hu/Adatgyüjtések/Népszámlálás, mikrocenzus/Kiadványok/Országos és területi adatok/2011. évi népszámlálás - Területi adatok - 3.1.-3.20 kötetek, Táblázatok, 3.1.4.1. tábla.

10. www.ksh.hu/Adatgyüjtések/Népszámlálás, mikrocenzus/Kiadványok/Országos és területi adatok/2011. évi népszámlálás - Területi adatok - 3.16. kötet, Táblázatok, 3.1.6.1. tábla.

11. www.ksh.hu/Adatgyüjtések/Népszámlálás, mikrocenzus/Kiadványok/Országos és területi adatok/2011. évi népszámlálás - Területi adatok - 3.16. kötet, Táblázatok, 3.1.5.1. tábla.

12. www.ksh.hu/Adatgyüjtések/Népszámlálás, mikrocenzus/Korábbi népszámlálások/Népszámlálás 2001/A 2001. évi népszámlálás kiadványai és adatai/ 6. Területi adatok/Táblázatok/Szabolcs-Szatmár-Bereg/4. Településenkénti adatok/ 4.2.1.2-4.2.1.3. tábla.

13. www.ksh.hu/Adatgyüjtések/Népszámlálás, mikrocenzus/Kiadványok/Országos és területi adatok/2011. évi népszámlálás - Területi adatok - 3.16. kötet, Táblázatok, 3.1.1.1, 3.1.5.1. tábla. 
14. www.ksh.hu/Adatgyüjtések/Népszámlálás,

mikrocenzus/Kiadványok/Országos és területi adatok/2011. évi népszámlálás

- Területi adatok - 3.1.-3.20 kötetek, Táblázatok, 3.1.1.1, 3.1.5.1. tábla.

15. www.ksh.hu/Adatgyüjtések/Népszámlálás,

mikrocenzus/Kiadványok/Országos és területi adatok/2011. évi népszámlálás - Területi adatok - 3.16. kötet, Táblázatok, 3.2.2.1. tábla.

16. www.ksh.hu/Adatgyüjtések/Népszámlálás, mikrocenzus/Korábbi népszámlálások/Népszámlálás 2001/A 2001. évi népszámlálás kiadványai és adatai/ 6. Területi adatok/Táblázatok/Szabolcs-Szatmár-Bereg/3. településtípusonkénti adatok/3.3.1. tábla.

17. www.ksh.hu/Adatgyüjtések/Népszámlálás,

mikrocenzus/Kiadványok/Országos és területi adatok/2011. évi népszámlálás - Területi adatok - 3.16. kötet, Táblázatok, 3.2.3.1. tábla.

18. www.ksh.hu/Adatgyüjtések/Népszámlálás, mikrocenzus/Korábbi népszámlálások/Népszámlálás 2001/A 2001. évi népszámlálás kiadványai és adatai/ 6. Területi adatok/Táblázatok/Szabolcs-Szatmár-Bereg/3. településtípusonkénti adatok/3.3.2.tábla.

Malakucziné Póka Mária: főosztályvezető

Központi Statisztikai Hivatal Debreceni Föosztály, 4400 Nyíregyháza, Sóstói u. 2-4. 